Article

\title{
Double Linker Triphenylamine Dyes for Dye-Sensitized Solar Cells
}

\author{
Peter J. Holliman ${ }^{1} * \mathbb{C}$, Moneer Mohsen ${ }^{2}$, Arthur Connell ${ }^{1}$, Christopher P. Kershaw ${ }^{1}$ (D), \\ Diana Meza-Rojas ${ }^{1}$, Eurig W. Jones ${ }^{1}{ }^{\mathbb{D}}$, Dawn Geatches ${ }^{3}\left(\mathbb{D}\right.$, Kakali Sen ${ }^{3}{ }^{\mathbb{D}}$ and Ya-Wen Hsiao ${ }^{3}$ \\ 1 College of Engineering, Bay Campus, Swansea University, Swansea SA1 8EN, UK; \\ arthur.connell@swansea.ac.uk (A.C.); c.p.kershaw@swansea.ac.uk (C.P.K.); \\ D.E.Mezarojas@Swansea.ac.uk (D.M.-R.); Eurig.W.Jones@Swansea.ac.uk (E.W.J.) \\ 2 Ministry of Science and Technology, Materials Research Directorate, Baghdad, Iraq; \\ moneer.69nm@yahoo.com \\ 3 Scientific Computing Department, STFC Daresbury Laboratory, Daresbury, Warrington WA4 4AD, UK; \\ dawn.geatches@stfc.ac.uk (D.G.); kakali.sen@stfc.ac.uk (K.S.); ya-wen.hsiao@stfc.ac.uk (Y.-W.H.) \\ * Correspondence: p.j.holliman@swansea.ac.uk
}

Received: 31 July 2020; Accepted: 3 September 2020; Published: 7 September 2020

\begin{abstract}
Most organic dyes synthesized for dye-sensitized solar cells (DSC) use a single linker group to bind to the metal oxide photo-anode. Here we describe the synthesis and testing of two new triphenylamine dyes containing either two carboxylic acids 5-[2-(4-diphenylamino-phenyl)-vinyl]-isophthalic acid (10) or two cyanoacrylic acids (2Z, 2' Z)-3, 3'-(5-((E)-4-(diphenylamino) styryl)-1, 3-phenylene) bis (2-cyanoacrylic acid) (8) as linker groups. Full characterization data are reported for these dyes and their synthetic intermediates. DSC devices have been prepared from these new dyes either by passive or fast dyeing and the dyes have also been tested in co-sensitized DSC devices leading to a PCE $(\eta=5.4 \%)$ for the double cyanoacrylate linker dye (8) co-sensitized with D149. The dye: $\mathrm{TiO}_{2}$ surface interactions and dye excitations are interpreted using three modelling methods: density functional theory (at $0 \mathrm{~K}$ ); molecular dynamics (at $298 \mathrm{~K}$ ); time dependent density functional theory. The modelling results show the preferred orientation of both dyes on an anatase $\left(\begin{array}{lll}1 & 0 & 1\end{array}\right) \mathrm{TiO}_{2}$ surface to be horizontal, and both the simulated and experimental absorption spectra of the dye molecules indicate a red shifted band for (8) compared to (10). This is in line with broader light harvesting and $\mathrm{J}_{\mathrm{sc}}$ for (8) compared to (10).
\end{abstract}

Keywords: light harvesting; co-sensitization; surface engineering; synthesis; solar energy; atomistic modelling; DFT; MD; TDDFT

\section{Introduction}

O'Regan and Grätzel's breakthrough paper in dye-sensitized solar cells (DSC) used the Ru-bipyridyl dye (N3) adsorbed on a mesoporous $\mathrm{TiO}_{2}$ photoanode leading to a power conversion efficiency (PCE) of 7.2\% [1]. Given this step forward, it is not surprising that a great deal of subsequent work focused on Ru-based dyes including N719 [2] and C101 [3] and "black dye" [4]. Whilst the development of these new dyes raised the PCE of DSC devices to ca. 11\%, further increases stalled. This was partly because the light harvesting of Ru-bipyridyl dyes is generally limited to $<650 \mathrm{~nm}$ and partly due to the relatively average molar extinction coefficients of Ru-bipyridyl dyes (extinction coefficient $=12,000-18,000 \mathrm{M}^{-1} \mathrm{~cm}^{-1}$ ) [5].

Following the Ru-bipyridyl dyes, two main approaches have been taken to further improve DSC device efficiencies. Firstly, organic dyes have been developed both for DSC and other photovoltaic solar cells [6]. For DSC, these dyes have been designed with higher extinction coefficient and, 
secondly, to be co-sensitized with more than one dye to broaden light harvesting across a wider part of the solar spectrum. To date, organic dyes have generally been designed using an intra-molecular donor-spacer-acceptor (D- $\pi$-A) arrangement to improve electron injection into the photoanode $[7,8]$ Examples of D- $\pi$-A dyes include 3,4-ethylenedioxythiophene (EDOT) [9], half-squaraine [10-12], perylene [13,14], and porphyrin [15] dyes. Dyes incorporating a D- $\pi$-A structure has led to several recent reports of DSC devices achieving PCE > 12\% [13-16] with the highest PCE of 14.7\% [17]. Another widely studied family of DSC dyes are triphenylamine dyes (TPA) [18,19]. Reports of TPA dyes which have studied dye: $\mathrm{TiO}_{2}$ interactions include using dye modifications to block liquid electrolyte recombination [20], to avoid co-sorbents [21], to improve charge transfer [22], and to operate efficiently at low light levels [23].

Holliman et al. also showed successful co- and tri-sensitization using a TPA with N719 [18]; an approach also used recently by Wu et al. [24]. Co-sensitization has also been shown to be important to increase spectral response, which increases photocurrent and PCE. One approach has been stepwise immersion with an intermediate $\mathrm{Al}_{2} \mathrm{O}_{3}$ layer; e.g., Durrant et al. used a Ru-bipyridyl dye and then a Ru-phthalocyanine dye [25] and Choi et al. used JK2 and then SQ1 to give $\eta=8.65 \%$ [26]. Slow, passive dyeing has also been used [27-29] leading to $12 \%$ efficiency for zinc porphyrin co-sensitized with organic dye CD5 [15] and 14.7\% for silyl and carboxylate linker dyes [17]. Work in our laboratory has demonstrated that ultra-fast dyeing and co-sensitization is possible in minutes [30,31] and can adsorb two or more dyes and also selectively desorb and re-adsorb dyes [32]. The influence of multiple linkers to chemisorb dyes onto $\mathrm{TiO}_{2}$ has also been studied in n-type [8,33] and p-type DSC devices [34].

In this paper, we report the synthesis of two new triarylamine dyes with double linker groups for adsorption onto $\mathrm{TiO}_{2}$ photo-anodes. These new dyes have been fully characterized (including single crystal X-ray crystallography) and have been tested in DSC devices leading to power conversion efficiencies of $1.2 \%$ for the double carboxylate dye (10) and $2.4 \%$ for the double cyanoacrylate linker dye (8). Ultra-fast co-sensitization has also been examined for these dyes which consistently shows improved light harvesting (i.e., higher $\mathrm{J}_{\mathrm{sc}}$ ) and PCE with the highest efficiency achieved for a combination of (8) and D149 (PCE $=5.4 \%)$.

Previously, impedance spectroscopy has been used for interfacial studies of DSC devices [35-38] including the dye: $\mathrm{TiO}_{2}$ interface. We have previously applied this to single linker triphenylamine dyes structurally related to dyes (8) and (10) reported here [19]. Whilst this technique provides useful information about the electronic behavior of DSC devices, it does not study dye: $\mathrm{TiO}_{2}$ orientation which is a key focus for this paper. To explore further the bonding interactions between the two dyes and the $\mathrm{TiO}_{2}$ anatase $\left(\begin{array}{lll}1 & 0 & 1\end{array}\right)$ surfaces, we used three atomistic modelling techniques: ab initio electronic structure calculations using density functional theory (DFT), classical molecular dynamics (MD), and time dependent density functional theory (TDDFT). These three methods together provide complementary characterization of the dye: $\mathrm{TiO}_{2}$ systems: DFT elucidates the electronic structure of the dye: $\mathrm{TiO}_{2}$ surfaces and the probable orientation of the dyes on the surface at $0 \mathrm{~K}$; MD shows the effect of temperature on the dye orientation and the bonding interactions; TDDFT explores the electronic excitations within the pure dye molecules in gas-phase and simulates absorption spectra and identifies the sites of intramolecular electron transfer on photo-excitation. The 'computational cost' i.e., number of processors and calculation time generally increases from MD $<$ DFT $<$ TDDFT which is reflected in the type, number, and composition of existing studies. For example, using DFT, dye molecules are often modelled in the gas-phase [39-41]; in dye: $\mathrm{TiO}_{2}$ systems the dyes are modelled attached to a few $\mathrm{TiO}_{2}$ units [42,43] or as dye: $\mathrm{TiO}_{2}$ cluster models [44-49], with fewer reported studies of crystalline (i.e., periodic) dye: $\mathrm{TiO}_{2}$ systems $[46,50]$ - a category to which our work is contributing.

By comparing the total energies of dye: $\mathrm{TiO}_{2}$ systems (at $0 \mathrm{~K}$ ) where the dye is oriented horizontally and vertically to the surface, we found that horizontal adsorption is the energetically preferred mode for both the double carboxylate and double cyanoacrylate linker dyes. We then used these models as the starting point for MD simulations run at $298 \mathrm{~K}$ for $40 \mathrm{~ns}$. 


\section{Materials and Methods}

\subsection{Dye Synthesis}

2.1.1. Synthesis of (2Z, 2'Z)-3, 3'-(5-((E)-4-(diphenylamino) styryl)-1, 3-phenylene) bis (2-cyanoacrylic acid) (8)

To (E)-5-(4-(diphenylamino) styryl) isophthalaldehyde (7) $(0.3 \mathrm{~g}, 0.74 \mathrm{mmol})$ in $20 \mathrm{~mL} \mathrm{CH} \mathrm{CH}_{3} \mathrm{CN}$ was added $(1.2 \mathrm{~g}, 14.8 \mathrm{mmol})$ of cyanoacetic acid and $0.6 \mathrm{~mL}$ of piperidine. The mixture was stirred at $90^{\circ} \mathrm{C}$ for $3 \mathrm{~h}$ under $\mathrm{N}_{2}$. After cooling to room temperature, the solution was poured into a mixture of $\mathrm{CH}_{2} \mathrm{Cl}_{2}$ and $\mathrm{H}_{2} \mathrm{O}(1: 1, v / v)$. The $\mathrm{pH}$ was adjusted to $\mathrm{pH}=2$ with $\mathrm{H}_{3} \mathrm{PO}_{4}$ and the mixture was extracted in a separation funnel and a red-orange precipitate formed in organic layer. This solid was filtered and purified by column chromatography over silica gel using petroleum spirit/ $\mathrm{CH}_{2} \mathrm{Cl}_{2}$ $(3: 1, v / v)$. The product was identified using TLC and the product was collected after removing the solvent by rotary evaporation under reduced pressure to produce (8) as a red-orange solid $(0.28 \mathrm{~g}$, $34.5 \%$ ), m.p. $262-264{ }^{\circ} \mathrm{C}$ (decompose). FTMS $^{+}$-MS: $m / z$ (Accurate Mass), reference compound: DEA, calcd. for $\mathrm{C}_{34} \mathrm{H}_{22} \mathrm{~N}_{3} \mathrm{O}_{4} 536.1616$, found $536.1612[\mathrm{M}-\mathrm{H}]^{-}$. ${ }^{1} \mathrm{H}$ NMR (400 MHz, DMSO) $\delta 6.96(d$, $\left.\left.J=8.56 \mathrm{~Hz}, 2 \mathrm{H},-\mathrm{Ph}-\mathrm{N}-\mathrm{Ph}_{2}\right), 7.08(m, 6 \mathrm{H},-\mathrm{N}-\mathrm{Ph})_{2}\right), 7.16($ br d $, 1 \mathrm{H}, J=16.04,-\mathrm{CH}=\mathrm{CH}-\mathrm{Ph}), 7.24($ br d, $1 \mathrm{H}$, $J=16.28,-\mathrm{CH}=\mathrm{CH}-\mathrm{Ph}), 7.33\left(t, J=7.6 \mathrm{~Hz}, 4 \mathrm{H},-\mathrm{N}-\mathrm{Ph}_{2}\right), 7.53\left(d, J=8.5 \mathrm{~Hz}, 2 \mathrm{H},-\mathrm{Ph}-\mathrm{N}-\mathrm{Ph}_{2}\right), 7.91(s, 2 \mathrm{H}$, $=\mathrm{CH}-\mathrm{Ph}-\mathrm{CH}=), 8.01(\mathrm{~s}, 1 \mathrm{H},=\mathrm{CH}-\mathrm{Ph}-\mathrm{CH}=), 8.10(\mathrm{~s}, 2 \mathrm{H},-\mathrm{C}=\mathrm{CH}-\mathrm{Ph}-) .{ }^{13} \mathrm{C}$ NMR $\left(100 \mathrm{MHz}, \mathrm{DMSO}-d_{6}\right)$ shows peaks at $\delta 115.99(-\underline{C \equiv N}), 122.06,123.03,123.92,127.56,129.14,129.76,129.84(\underline{A r-C}-\mathrm{H}), 124.07$, 130.33 (Ar- $\underline{\mathrm{CH}=\mathrm{CH}}-\mathrm{Ar}), 132.89,138.58(\underline{\mathrm{Ar}-\mathrm{C}-\mathrm{C})}, 146.32,146.92(\underline{\mathrm{Ar}-\mathrm{C}-\mathrm{N}-)}, 150.97$ (Ar-C-CH$-\mathrm{C}-\mathrm{CN})$,

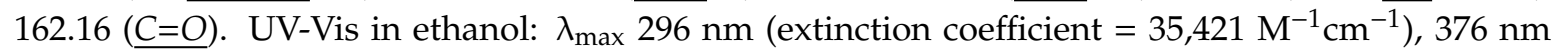
(extinction coefficient $\left.=20,869 \mathrm{M}^{-1} \mathrm{~cm}^{-1}\right)$. FT-IR spectrum $(\mathrm{KBr}) v / \mathrm{cm}^{-1}: 3200-2700 \mathrm{~cm}^{-1} v(\mathrm{O}-\mathrm{H}, \mathrm{br})$ carboxylic acid; $3032 \mathrm{~cm}^{-1} \vee(\mathrm{C}-\mathrm{H}, \mathrm{m})$ aromatic; $2928 \mathrm{~cm}^{-1} \vee(\mathrm{C}-\mathrm{H}, \mathrm{m})$ aliphatic; $2226 \mathrm{~cm}^{-1} \vee(\mathrm{C} \equiv \mathrm{N}, \mathrm{m})$; $1723 \mathrm{~cm}^{-1} \vee(\mathrm{C}=\mathrm{O}, \mathrm{str}) ; 1587 \mathrm{~cm}^{-1} \vee(\mathrm{C}=\mathrm{C}, \mathrm{shp})$ aromatic; $1493 \mathrm{~cm}^{-1} \vee(\mathrm{C}=\mathrm{C}, \mathrm{str})$ aliphatic; $1273 \mathrm{~cm}^{-1}$ $v(\mathrm{C}-\mathrm{O}, \mathrm{str}) ; 1177 \mathrm{~cm}^{-1} v(\mathrm{C}-\mathrm{N}, \mathrm{str}) ; 1050 \mathrm{~cm}^{-1} v(\mathrm{C}-\mathrm{H}, \mathrm{str})$ bending, $963 \mathrm{~cm}^{-1}(\mathrm{C}-\mathrm{N}, \mathrm{m})$ bending.

\subsubsection{Synthesis of 5-[2-(4-Diphenylamino-phenyl)-vinyl]-isophthalic Acid (10)}

5-[(2-diphenylamino-phenyl)-vinyl]-isophthalic acid dimethyl ester (9) $(0.33 \mathrm{~g}, 0.71 \mathrm{mmol})$ was dissolved in $10 \mathrm{~mL}$ THF with $1.2 \mathrm{~mL}$ methanol and $1.3 \mathrm{~mL} \mathrm{H}_{2} \mathrm{O}$ and 30 eq. $(0.85 \mathrm{~g}, 0.71 \mathrm{mmol})$ of $\mathrm{LiOH}$. The mixture was stirred overnight at $45^{\circ} \mathrm{C}$. After that, the solution was cooled to room temperature. A $5 \%$ solution of hydrochloric acid was added drop wise and the $\mathrm{pH}$ adjusted to between 5 and 6 . The solution was then quenched with water. The product was extracted with ethyl acetate $(3 \times 50 \mathrm{~mL})$, and the organic layer dried using anhydrous $\mathrm{MgSO}_{4}$. The solvent was evaporated using a rotary evaporator under vacuum to produce 5-[2-(4-diphenylamino-phenyl)-vinyl]-isophthalic acid (10) as a yellow solid (yield $0.27 \mathrm{~g}, 87 \%$ ) m.p. $300-302{ }^{\circ} \mathrm{C}$. A suitable crystal for X-ray analysis was prepared by dissolving (10) in $\mathrm{CH}_{2} \mathrm{Cl}_{2} /$ diethyl ether $(1: 1, v / v)$ followed by slow evaporation.

FTMS ${ }^{+}$-MS: $m / z$ (Accurate Mass), reference compound: $\mathrm{NH}_{4} \mathrm{OAc}$, calcd. for $\mathrm{C}_{28} \mathrm{H}_{21} \mathrm{NO}_{4}, 436.1543$, found $436.1542[\mathrm{M}+\mathrm{H}]^{+}$. Anal. Calcd. for $\mathrm{C}_{28} \mathrm{H}_{21} \mathrm{NO}_{4}: \mathrm{C}, 77.23 ; \mathrm{H}, 4.86 ; \mathrm{N}, 3.22$. Found: $\mathrm{C}$, 76.07; H, 4.96; N, 3.11. ${ }^{1} \mathrm{H}$ NMR $\left(500 \mathrm{MHz}, \mathrm{DMSO}-d_{6}\right) \delta 6.96(\mathrm{~d}, J=8.5 \mathrm{~Hz}, 2 \mathrm{H},-\mathrm{Ph}-\mathrm{N}-\mathrm{Ph} 2), 7.05$ (d, $J=7.6 \mathrm{~Hz}, 4 \mathrm{H}, \mathrm{Ph}-\mathrm{N}-\mathrm{Ph} 2), 7.08$ (t, $J=7.25 \mathrm{~Hz}, 2 \mathrm{H},-\mathrm{Ph}-\mathrm{N}-\mathrm{Ph} 2), 7.28-7.39$ (m, 6H, -Ph-N-Ph2, $\mathrm{Ph}-\mathrm{CH}=\mathrm{CH}-\mathrm{Ph}, \mathrm{Ph}-\mathrm{CH}=\mathrm{CH}-\mathrm{Ph}), 7.59$ (d, $J=8.8 \mathrm{~Hz}, 2 \mathrm{H},-\mathrm{Ph}-\mathrm{N}-\mathrm{Ph} 2), 8.32$ (s, 3H, =CH-Ph-COOH); ${ }^{13} \mathrm{C}$ NMR $\left(125 \mathrm{MHz}, \mathrm{DMSO}-d_{6}\right) \delta 122.17,122.67,123.19,123.61,126.09,128.04,129.11$ (Ar-C-H), 124.31, 129.64 (Ar-CH=CH-Ar), 130.13, 130.54, 151.30 (Ar-C-C), 142.71, 146.89 (Ar-C-N), 166.66 $(C=O)$. UV-Vis in ethanol: $\lambda_{\max } 296 \mathrm{~nm}$ (extinction coefficient $=25,718 \mathrm{M}^{-1} \mathrm{~cm}^{-1}$ ), $372 \mathrm{~nm}$ (extinction coefficient $\left.=35,218 \mathrm{M}^{-1} \mathrm{~cm}^{-1}\right)$. FT-IR spectrum $(\mathrm{KBr}) v / \mathrm{cm}^{-1}: 3400-2700 \mathrm{~cm}^{-1} v(\mathrm{O}-\mathrm{H}$, br $)$ carboxylic acid; $3041 \mathrm{~cm}^{-1} \vee(\mathrm{C}-\mathrm{H}, \mathrm{m})$ aromatic; $2926 \mathrm{~cm}^{-1} v(\mathrm{C}-\mathrm{H}, \mathrm{m})$ aliphatic; $1699 \mathrm{~cm}^{-1} v(\mathrm{C}=\mathrm{O}, \mathrm{shp}) ; 1589 \mathrm{~cm}^{-1}$ $v(\mathrm{C}=\mathrm{C}, \mathrm{shp})$ aromatic; $1492 \mathrm{~cm}^{-1} \vee(\mathrm{C}=\mathrm{C}, \mathrm{shp})$ aliphatic; $1280 \mathrm{~cm}^{-1} \vee(\mathrm{C}-\mathrm{N}, \mathrm{str}) ; 961 \mathrm{~cm}^{-1}$ for $(\mathrm{C}-\mathrm{N}$, $\mathrm{m})$ bending. 


\subsection{Device Making and Testing}

DSC active areas were prepared by doctor blading two layers of transparent $\mathrm{TiO}_{2}$ paste (DSL18NRT, Dyesol) onto fluoride tin oxide-coated glass (TEC15, NSG) followed by one layer of scattering $\mathrm{TiO}_{2}$ paste (WER4-O, Dyesol) to produce ca. $12 \mu \mathrm{m}$ thick films. The $\mathrm{TiO}_{2}$ films were shaped to $0.5 \times 2 \mathrm{~cm}$ to give $1.0 \mathrm{~cm}^{2}$ devices and each $\mathrm{TiO}_{2}$ layer was sintered at $450{ }^{\circ} \mathrm{C}$ for $30 \mathrm{~min}$. $\mathrm{The}^{\mathrm{TiO}} \mathrm{O}_{2}$ films were then immersed in $50 \mathrm{mM} \mathrm{TiCl}_{4}: \mathrm{THF}_{2(\mathrm{aq})}$ at $70{ }^{\circ} \mathrm{C}$ for $30 \mathrm{~min}$, rinsed with DI water, air-dried for $10 \mathrm{~min}$ and re-sintered at $450{ }^{\circ} \mathrm{C}$ for $10 \mathrm{~min}$. The $\mathrm{TiO}_{2}$ films were either dyed passively ( $18 \mathrm{~h}$ immersion in dye solution) or ultra-fast dyed ( $5 \mathrm{~min}$ ) according to Holliman et al. [29]. The counter electrode (TEC 8, NSG) was coated with Pt paste (PT1, Dyesol) and heated to $400{ }^{\circ} \mathrm{C}$. The two electrodes were sealed with a Surlyn gasket (DuPont) at $120^{\circ} \mathrm{C}$. Iodide/tri-iodide electrolyte $\left(\mathrm{I}_{2} 100 \mathrm{mM}\right.$, imidazolium iodide $0.8 \mathrm{~mol} \mathrm{~L}^{-1}$ and LiI $100 \mathrm{mmol} \mathrm{L}^{-1}$ in distilled 3-methoxypropionitrile) was added through holes in the counter electrode which were then sealed using Surlyn (DuPont). Current-voltage characteristics were measured with an ABET Solar Simulator with a Xe arc lamp and a Keithley 2400 at $100 \mathrm{~mW} \mathrm{~cm}{ }^{2}$ (1 Sun). Spectral response was measured on a QEX10 Quantum Efficiency Measurement System in DC mode at a resolution of $10 \mathrm{~nm}$. Lamps were calibrated using a certified (Oriel 91,150 V) monocrystalline Si reference cell traceable to the National Renewable Energy Laboratory (NREL).

\subsection{Atomistic Modelling Simulations}

The ab initio electronic structure calculations were carried out using the plane wave, pseudopotential code [51] within the formalism of density functional theory (DFT) [52-54]. The dye: $\mathrm{TiO}_{2}$ models were built using Materials Studio [55] and the calculations were run on 192 processors per model system. Previous atomistic modelling work on six half-squaraine dye molecules adsorbed on anatase $\mathrm{TiO}_{2}\left(\begin{array}{lll}1 & 0 & 1\end{array}\right)$ [11] surface involved scanning a range of dye orientations in an attempt to identify the most probable mode of adsorption, i.e., the orientation of the dye on the surface that corresponded to the lowest energy. All six half-squaraine dyes preferred a horizontal orientation to the surface [12]. The carboxylic group of the dye: $\mathrm{TiO}_{2}$ system was either directly bonded to the surface via O-Ti, and/or via a hydrogen bond; the cyano-dye was also bonded via N-Ti.

Whilst both double-linker dyes ((8) and (10)) contain carboxylic linker groups, dye (8) contains two cyanoacrylate linker groups (i.e., both linkers have an additional nitrile unit). Based on the findings from the aforementioned (half-squaraine) work, that data suggests that attachment to the $\mathrm{TiO}_{2}$ surface occurs via the nitrile moieties of vinyl dicyano units on derivatized half-squaraine dyes. Therefore, we focused the atomistic modeling for dyes (8) and (10) on vertical (the commonly hypothesized orientation in the dye sensitized research community), and horizontal dye-to-surface orientations only; the symmetry of the dyes along their carbon backbone excluded side orientations. Dye molecules (8) and (10) were placed horizontally and vertically oriented to the $\mathrm{TiO}_{2}$ surface, and then allowed to relax to their lowest energy configurations at $0 \mathrm{~K}$; i.e., until the convergence criteria were met. Further details of the model system set-up and convergence criteria are in the Supplementary Material.

The molecular dynamics simulations were carried out using NAMD [56]. The models were built and visualized using VMD [57] and the calculations were run on 64 processors. The dyes were placed vertically on a fixed slab, before each dye: $\mathrm{TiO}_{2}$ system underwent minimization, equilibration, and simulation at $298 \mathrm{~K}$ in an NVT ensemble. Further details of the simulation parameters and run can be found in the Supplementary Material.

A common method to study electronic excited states within the DFT framework is via time-dependent (TD) DFT [58-61]. The dyes were optimized at their ground state in gas-phase using DFT. The excited states were calculated with TDDFT and all calculations were done using the ORCA software package [62] and run on 32 processors. Further details of the TDDFT parameters can be found in the Supplementary Material. 


\section{Results and Discussion}

\subsection{Dye Synthesis}

Dyes (8) and (10) were synthesized using the methods shown in Scheme 1.

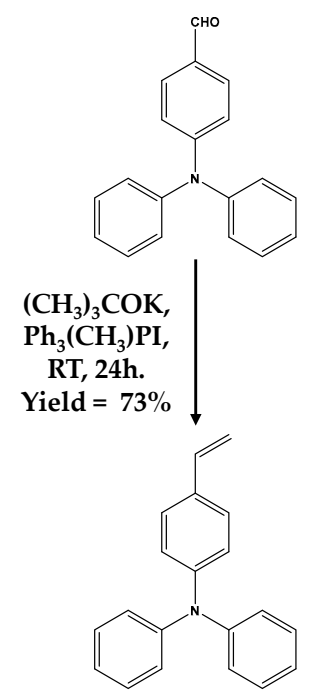

(1)
(1)

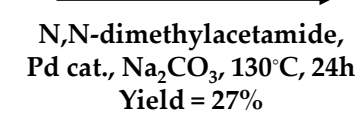

N,N-dimethylacetamide, Yield $=27 \%$

(6)
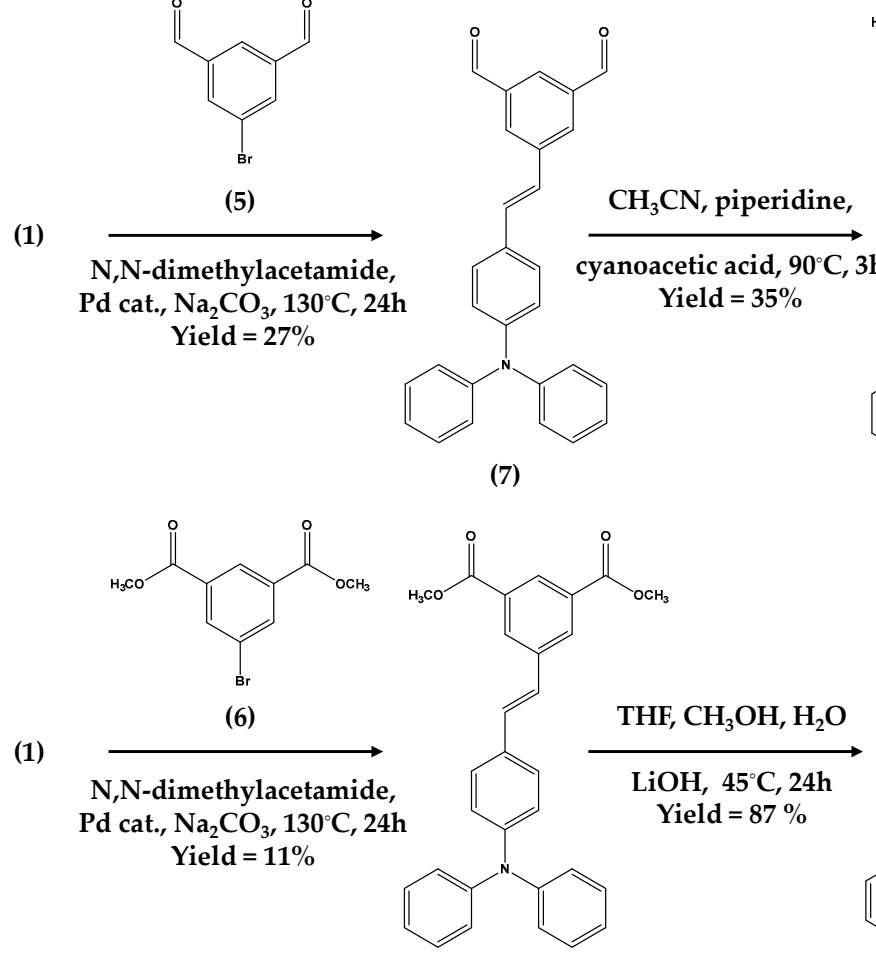

(7)

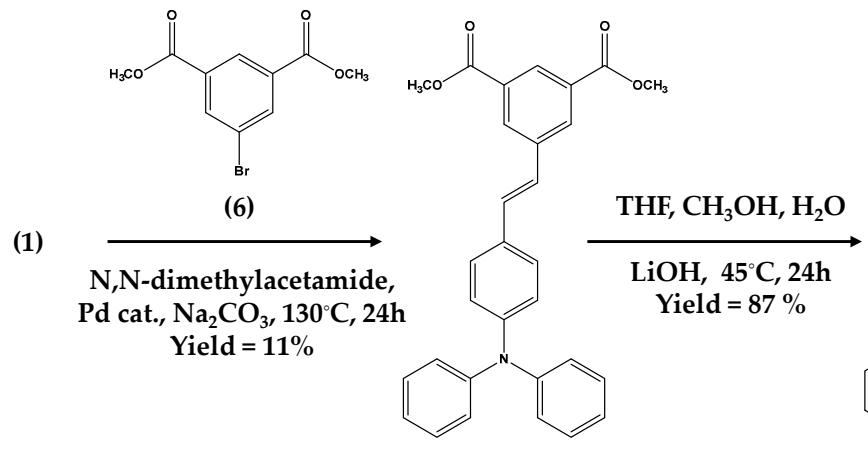

(1)
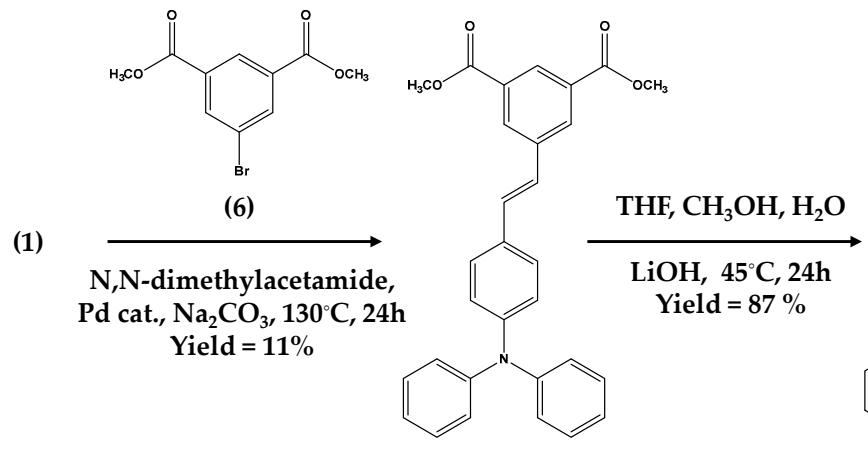

(9)

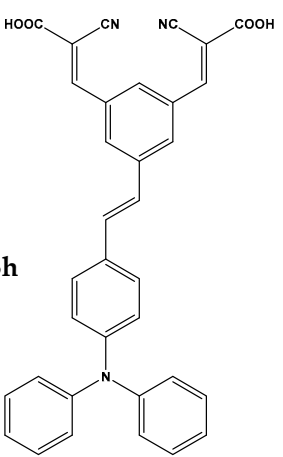

(8)

Scheme 1. Synthetic pathway for dyes (8) and (10). Pd cat = trans-di( $\mu$-acetato)bis[0

Scheme 1. Synthetic pathway for dyes (8) and (10). Pd cat $=$ trans-di( $\mu$-acetato)bis $[0$
-(di-0-tolylphosphoino)benzylldipalladium (II). Compounds (1) to $(\mathbf{9})$ are described in the supplementary material (SM).

Dye (8) was synthesized by first converting 4-(N, N-diphenylamino)-benzaldehyde to the known compound (4-vinyl-phenyl)-amine (1) by a Wittig reaction [19]. This was confirmed by NMR and mass spectrometry (see Supplementary Material). To make the double cyanoacrylate linker, bromo-isophthalic acid was esterified using methanol and $\mathrm{H}_{2} \mathrm{SO}_{4}(\mathrm{aq})$ to make the dimethyl ester (6). Then, (6) was reduced to the di-alcohol (4) using $\mathrm{LiAlH}_{4}$ (see Supplementary Material). This reaction was followed by TLC before quenching with $\mathrm{Na}_{2} \mathrm{SO}_{4(\mathrm{aq})}$. The product was confirmed by ${ }^{1} \mathrm{H} \mathrm{NMR}$ with alcohol protons $\left(2 \mathrm{x}-\mathrm{CH}_{2} \mathrm{OH}\right)$ at $4.63 \mathrm{ppm}$ as a singlet whilst ${ }^{13} \mathrm{C}$ NMR (DEPTQ) shows five carbon environments and a new signal at $63.01 \mathrm{ppm}$ for $\left(-\mathrm{CH}_{2}-\mathrm{OH}\right)$. Mass spectrometry confirmed (4) with $\left[\mathrm{M}+\mathrm{NH}_{4}\right]^{+}$at 234.0126 . The di-aldehyde (5) was synthesized by oxidizing (4) with pyridinium chlorochromate which was confirmed by the loss of $\mathrm{CH}_{2} \mathrm{OH}$ signals in the ${ }^{1} \mathrm{H}$ NMR data and the appearance a signal at $10.06 \mathrm{ppm}$ for the aldehyde. ${ }^{13} \mathrm{C}$ NMR data also showed a signal at $189.48 \mathrm{ppm}$ for the aldehyde carbons and mass spectrometry showed $[\mathrm{M}+\mathrm{H}]^{+}$at 212.9546 for (5). Combining (1) and (5) in a Heck coupling then produced (7) which was confirmed by triphenylamine-vinyl (6.97-8.39 ppm) and aldehyde (10.13 ppm) signals in the ${ }^{1} \mathrm{H}$ NMR data and $15 \mathrm{C}$ environments in the ${ }^{13} \mathrm{C}$ NMR data. Mass spectrometry also confirmed (7) with $[\mathrm{M}+\mathrm{H}]^{+}$at 404.1645 . Finally, (8) was synthesized by a Knoevenagel condensation reaction of (7) with cyanoacetic acid in the presence of piperidine. ${ }^{1} \mathrm{H}$ NMR data confirmed (8) with the loss of aldehyde signals. ${ }^{13} \mathrm{C}$ NMR data showed 18 carbon environments and a new signal at $115.99 \mathrm{ppm}$ for $(\mathrm{C} \equiv \mathrm{N})$ which was also confirmed by FT-IR with a new peak at $2226 \mathrm{~cm}^{-1}$. Mass spectrometry also confirmed (8) with $[\mathrm{M}-\mathrm{H}]^{-}$at 536.1612. 
Dye (10) was synthesized in three steps. First, 5-bromo isophthalic acid was esterified to 5-bromo-isophthalic acid dimethyl ester (6) using methanol and a few drops of $\mathrm{H}_{2} \mathrm{SO}_{4(\mathrm{aq})}$. The next step was to couple (1) with (6) to synthesize (9) which was confirmed by ${ }^{1} \mathrm{H}$ NMR data with a singlet at $3.91 \mathrm{ppm}$ for methyl ester groups and triphenylamine signals (6.96 to $8.38 \mathrm{ppm}$ ) and an ester carbonyl at $165.34 \mathrm{ppm}$ in the ${ }^{13} \mathrm{C}$ NMR data (see Supplementary Material). Mass spectrometry also confirmed $[\mathrm{M}+\mathrm{H}]^{+}$for (9) at 464.1852 (see ESI). Finally, (10) was synthesized by hydrolytic de-esterification of (9) using $\mathrm{LiOH}$ before $\mathrm{pH}$ adjustment with $\mathrm{HCl}$ to yield (10) as the acid form. Both ${ }^{1} \mathrm{H}$ NMR and ${ }^{13} \mathrm{C}$ NMR confirm the loss of the methyl ester groups and a shift of the carbonyl carbon from 165.34 to $166.63 \mathrm{ppm}$ for the carboxylic acid. Mass spectrometry also confirmed [M + H] ${ }^{+}$for (10) at 436.1542 .

The UV-Vis spectra of dyes (8) and (10) are shown in Figure 1, the data in Table 1, and also in the Supplementary Material Figure S2. For the solution spectra (Figure 1a), the main two peaks on the spectra are at similar positions (ca. 295 and $375 \mathrm{~nm}$ ) and are ascribed to a $\pi-\pi^{*}$ electron transition and intra-molecular charge transfer (i-MCT) between the triphenylamine donor and the acid acceptor of each dye. However, there is a difference in the relative intensities on these peaks between the two dyes. Thus, for (8) the $\pi-\pi^{*}$ transition is more intense (extinction coefficient $=35,421 \mathrm{M}^{-1} \mathrm{~cm}^{-1}$ ) relative to the i-MCT (extinction coefficient $=21,077 \mathrm{M}^{-1} \mathrm{~cm}^{-1}$ ). However, for (10) the opposite trend is observed; i.e., the $\pi-\pi^{*}$ transition is less intense (extinction coefficient $=25,718 \mathrm{M}^{-1} \mathrm{~cm}^{-1}$ ) relative to the i-MCT (extinction coefficient $=35,196 \mathrm{M}^{-1} \mathrm{~cm}^{-1}$ ). Importantly, the i-MCT peak for (8) is also much broader than for (10) and extends to ca. $500 \mathrm{~nm}$ which suggests a broader spectral response for (8). Figure $1 \mathrm{~b}$ shows UV-Vis spectral data for a pristine, mesoporous $\mathrm{TiO}_{2}$ film. The data show a strong absorbance band centered around $350 \mathrm{~nm}$ which continues up to approx. $390 \mathrm{~nm}$ as expected for anatase. Figure $1 \mathrm{~b}$ also shows data for dyes (8) and (10) adsorbed onto $\mathrm{TiO}_{2}$. For clarity, the dyes were measured using a pristine $\mathrm{TiO}_{2}$ film as the background so that only light absorption from the dyes is observed. For both of the adsorbed dyes (8) and (10), there is a slight red shift on the i-MCT band up to ca. $410 \mathrm{~nm}$. For adsorbed dye (10), the absorption onset red shifts up to ca. $475 \mathrm{~nm}$ from $450 \mathrm{~nm}$ for pristine (10). For adsorbed dye (8), the absorption onset red shifts even further up to ca. $550 \mathrm{~nm}$ from $500 \mathrm{~nm}$ for pristine (8). These data correlate strongly with the EQE data for these dyes (Figure 2a).
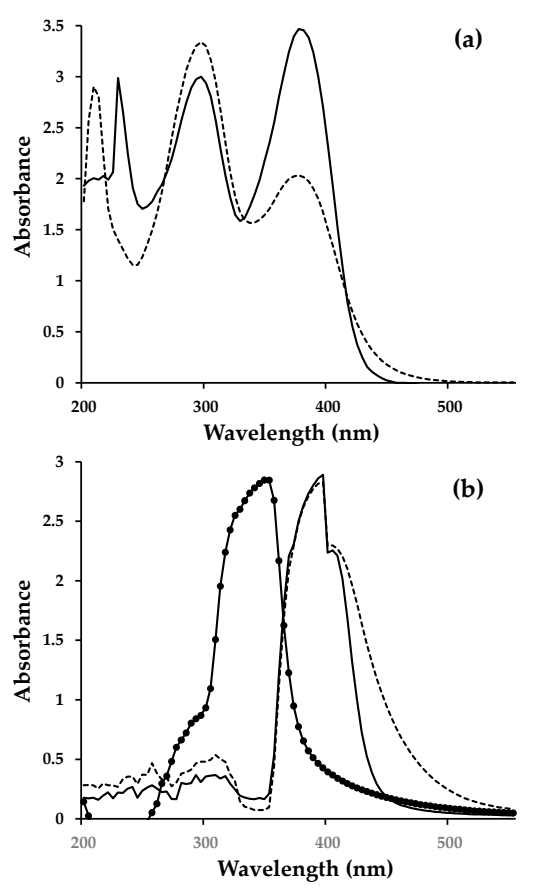

Figure 1. UV-visible spectra for (a) dyes dissolved in methanol and (b) dyes adsorbed onto a transparent, mesoporous $\mathrm{TiO}_{2}$ film. Key: Transparent $\mathrm{TiO}_{2}$ film—full line with circles; (8)—dashed line; (10)_full line. 
Table 1. Spectral data for solution and $\mathrm{TiO}_{2}$ adsorbed dyes.

\begin{tabular}{lcc}
\hline & $\mathbf{( 8 )}$ & $\mathbf{( 1 0 )}$ \\
\hline Linker group & Cyanoacrylate & Carboxylate \\
Absorbance maxima/nm and (extinction & $296(35,421)$ & $296(25,718)$ \\
coefficient/M & cm & -1 \\
Ethanol solution absorption onset/nm & $376(20,869)$ & $372(35,218)$ \\
Ethanol solution HOMO-LUMO gap/eV & 502 & 456 \\
$\mathrm{TiO}_{2}$ adsorbed absorption onset/nm & 2.47 & 2.72 \\
$\mathrm{TiO}_{2}$ adsorbed HOMO-LUMO gap/eV & 570 & 530 \\
\hline
\end{tabular}
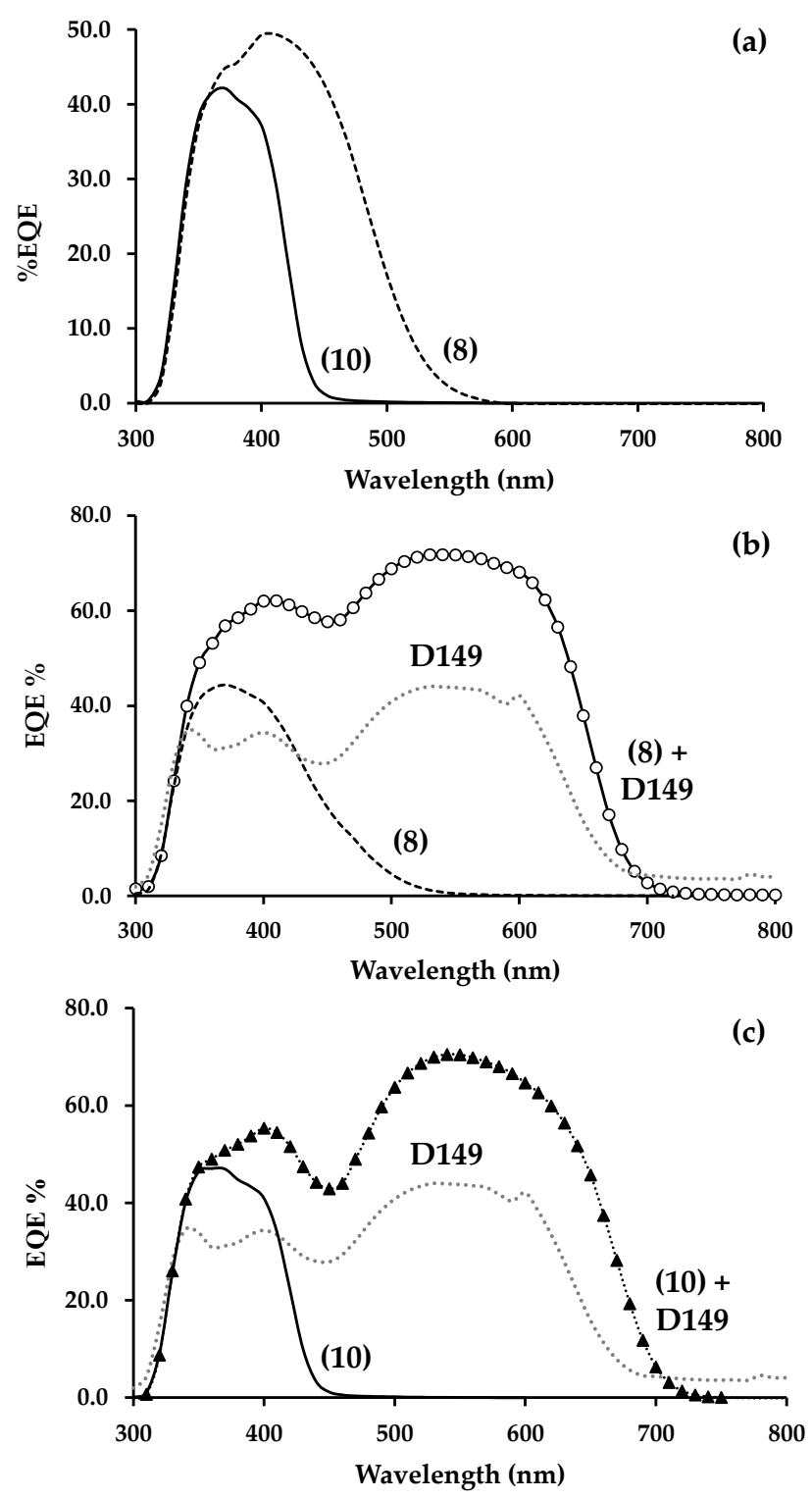

Figure 2. External quantum efficiency (EQE) versus wavelength for (a) singly dyed dye-sensitized solar cells (DSC) devices of (8) and (10), (b) singly dyed DSC devices of (8), D149 and co-sensitized (8) + D149 and (c) singly dyed DSC devices of (10), D149 and co-sensitized (10) + D149. 


\subsection{Device Performance}

\subsubsection{Experimental}

Table 2 and Supplementary Material Figure S3 show the data for DSC devices made using these new triphenylamine dyes. For $1 \mathrm{~cm}^{2}$ DSC devices made with only single dyes which have been passively dyed onto the $\mathrm{TiO}_{2}$ photoanodes, the data show power conversion efficiencies (PCE) of $\eta=2.4 \%$ and $1.2 \%$ for dyes (8) and (10), respectively. The higher PCE for (8) versus (10) is reflected in the higher photocurrent $\left(\mathrm{J}_{\mathrm{sc}}=5.37 \mathrm{~mA} \mathrm{~cm}^{-2}\right.$ versus $\left.2.82 \mathrm{~mA} \mathrm{~cm}^{-2}\right)$ and voltage $\left(\mathrm{V}_{\mathrm{oc}}=0.71 \mathrm{~V}\right.$ versus $0.63 \mathrm{~V})$, respectively. The higher photocurrent for (8) can be explained by the broader spectral response for this dye compared to (10). For example, EQE data for (8) shows light harvesting from ca. 320-550 nm whereas (10) only harvests light from ca. 320-450 nm (Figure 2a). Previously, we observed a higher photocurrent for a single cyanoacrylate linker triphenylamine dye over the analogous carboxylate dye [19] which again was due to a broader spectral response for the cyanoacrylate linker dye. However, previously, this was accompanied by a lower $\mathrm{V}_{\text {oc }}$. The data here suggest that having two cyanoacrylate linkers improves the voltage. The previously published indoline dye D149 was used as a control dye for these devices and this gave PCE of $4.4 \%$ for a $1 \mathrm{~cm}^{2}$ device. The $\mathrm{J}_{\mathrm{sc}}\left(13.50 \mathrm{~mA} \mathrm{~cm}{ }^{-2}\right)$ and $\mathrm{V}_{\mathrm{oc}}(0.60 \mathrm{~V})$ for this dye are similar (but slightly lower) to published data [63] which might be due to a larger device area for the devices here. The different colors of the two dyes will also inevitably reflect different dye energy levels (i.e., highest occupied molecular orbital-HOMO; lowest unoccupied molecular orbital-LUMO). For example, the absorption onset of (8) is at ca. $500 \mathrm{~nm}$ which corresponds to a HOMO-LUMO gap of ca. $2.48 \mathrm{eV}$, whilst for (10) the onset is ca. $430 \mathrm{~nm}$ which gives EB of $2.88 \mathrm{eV}$. It is not clear from these data whether this variance of $400 \mathrm{mV}$ reflects a shift in either the HOMO or LUMO levels of (8). However, if the LUMO did shift this might improve energy alignment with the $\mathrm{TiO}_{2}$ conduction band.

Table 2. I-V testing data for (8), (10), N719, and D149 devices.

\begin{tabular}{lccccc}
\hline \multicolumn{1}{c}{ Device } & Dye(s) & $\mathbf{H ~ ( \% )}$ & $\mathbf{F F}$ & $\mathbf{J}_{\mathbf{s c}}\left(\mathbf{m A} / \mathbf{c m}^{-\mathbf{2}}\right)$ & $\mathbf{V}_{\mathbf{o c}}(\mathbf{V})$ \\
\hline Passive dyed & & & & & \\
\hline A & $(\mathbf{8})$ & 2.4 & 0.63 & 5.37 & 0.71 \\
B & $(\mathbf{1 0})$ & 1.2 & 0.67 & 2.82 & 0.63 \\
C & D149 & 4.4 & 0.54 & 13.50 & 0.60 \\
\hline Fast dyed & & & & & \\
\hline D & N719 & 4.2 & 0.62 & 9.32 & 0.73 \\
E & $(\mathbf{8})$ & 2.6 & 0.72 & 4.53 & 0.76 \\
F & $(\mathbf{1 0})$ & 1.0 & 0.58 & 2.50 & 0.67 \\
G & D149 & 4.3 & 0.53 & 13.34 & 0.61 \\
H & $(\mathbf{8})+$ D149 & 5.4 & 0.59 & 14.69 & 0.58 \\
K & $(\mathbf{1 0}+$ D149 & 4.4 & 0.54 & 12.63 & 0.58 \\
L & $(\mathbf{8}+$ N719 & 2.1 & 0.58 & 5.82 & 0.62 \\
M & $(\mathbf{1 0})+$ N719 & 2.6 & 0.78 & 4.41 & 0.74 \\
\hline
\end{tabular}

Table 2 also shows data for ultra-fast dyed devices. When comparing between the passive and fast dying data there are no significant differences between (8) and (10) except that the $\mathrm{J}_{\mathrm{sc}}$ is decreased slightly for the fast-dyed devices which might suggest slightly lower dye loading. Devices $\mathrm{H}$ and $\mathrm{K}$ were prepared by co-sensitizing dyes (8+D149) and (10+D149), respectively. Device H shows improved data for co-sensitization compared with Device $C$ with an increase in efficiency from $4.3 \%$ to $5.4 \%$ and $\mathrm{J}_{\mathrm{sc}}$ from 13.34 to $14.69 \mathrm{~mA} \mathrm{~cm}^{-2}$. The EQE data for a combination of (8) and D149 (Device H and Figure 2b), shows a maximum EQE of $72 \%$ at $540 \mathrm{~nm}$ for D149 and of $62 \%$ at $410 \mathrm{~nm}$ for (8). Overall, these EQE data show higher spectral response and wider photon capture across solar spectrum for the co-sensitized devices leading to increase of $\mathrm{J}_{\mathrm{sc}}$. In contrast, Device $\mathrm{K}$ did not show as good a PCE compared with Device H or C. Figure 2c shows a maximum EQE of $71 \%$ at $540 \mathrm{~nm}$ for D149 and of 55\% at $400 \mathrm{~nm}$ for (10). The EQE data for Devices $\mathrm{L}$ and $\mathrm{M}$ which were made by co-sensitizing $(\mathbf{8}+\mathbf{N} 719)$ or (10+N719) (see Supplementary Material), were much lower and did not show as promising results 
which suggests that the lower extinction coefficient of N719 reduced photon harvesting meaning that more adsorbed dye was required to harvest the same amount of light.

Interestingly, a comparison of the UV-vis (Figure 1) and EQE data (Figure 2) shows that the light harvesting of both (8) and (10) is red shifted when the dyes are absorbed on $\mathrm{TiO}_{2}$ compared to in solution. Not only is this advantageous in terms of harvesting more light in the part of the AM1.5 spectrum where more sunlight is available, but it is also indicative of the bonding interactions between the dye and the $\mathrm{TiO}_{2}$. The gas phase spectra of dyes (8) and (10) were calculated using TDDFT (see Section 3.2.2. below). Although these calculations do not include solvent, they show similar trends in light absorption with (8) exhibiting red-shifted bands relative to (10).

\subsubsection{Simulation of the Dye Gas-Phase Spectra}

The TDDFT calculations show that the orbitals involved in the electronic excitations are $\pi-\pi^{*}$ in nature (Figure 3). The most intense peak (2 in (8) and 1 in (10)) for both the dyes involves similar $\pi-\pi^{*}$ orbitals and the transition occurs at $350.1 \mathrm{~nm}$ for (8) and $329.7 \mathrm{~nm}$ for (10). The major difference between the dyes' spectra is seen in the peak at $379.9 \mathrm{~nm}$ (peak 1 in Figure 3 ) in (8). This is also a $\pi-\pi^{*}$ transition. However, the $\pi^{*}$ of the LUMO is localized on the cyanoacrylate part of the molecule. This is important in the context of often quoted donor-linker-acceptor design for DSC dyes because the excited state LUMO is located on the linker part of the dye which should make electron injection into the $\mathrm{TiO}_{2}$ more favorable. Similar transitions involving $\pi-\pi^{*}$ orbitals, where the $\pi *$ is localized at the carboxylate part, is largely blue shifted $(296.7 \mathrm{~nm}$, peak 2 in figure) in (10). Whilst again the location of the LUMO on the linker part of (10) should favor electron injection into $\mathrm{TiO}_{2}$, for (10), the blue shift means that this transition is driven by the harvesting of lower solar intensity, higher energy photons which ultimately limits device photocurrent. Overall, we can say that the spectral transitions are red shifted for (8) - a trend similar to that observed experimentally.
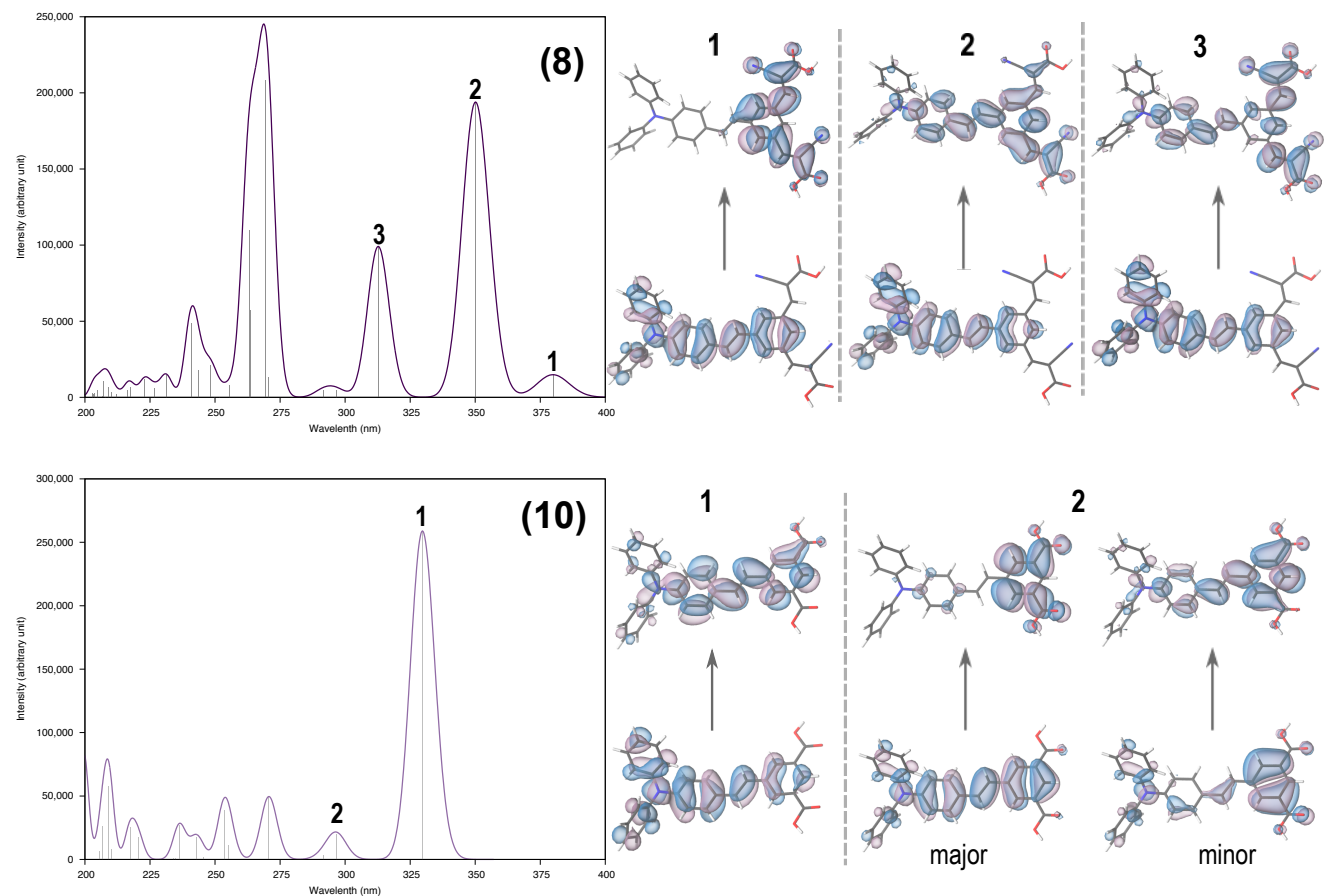

Figure 3. In the left panel are the simulated spectra of dyes (8) and (10) generated by the orca_mapspc utility program. In the right panel are the natural transition orbitals associated with the electronic transitions around and beyond $300 \mathrm{~nm}$ as marked on the spectra; the vertical arrows indicate a transition from an occupied orbital to an unoccupied orbital. The orbitals are plotted with an isosurface value of 0.02 a.u. 


\subsection{Bonding Interactions between the Dye and $\mathrm{TiO}_{2}$ Surface-Atomistic Modelling}

The final configurations of the dyes on the (1 01 l) anatase surface of $\mathrm{TiO}_{2}$ calculated using DFT are shown in Figure 4. The horizontal orientation of both dyes resulted in lower total energies than the vertical orientations. These findings agree with those we reported for the smaller, half-squaraine dyes [12] implying that the length of the dye molecule has no effect on the tendency of a dye to lie horizontally to the surface at $0 \mathrm{~K}$.

(8)

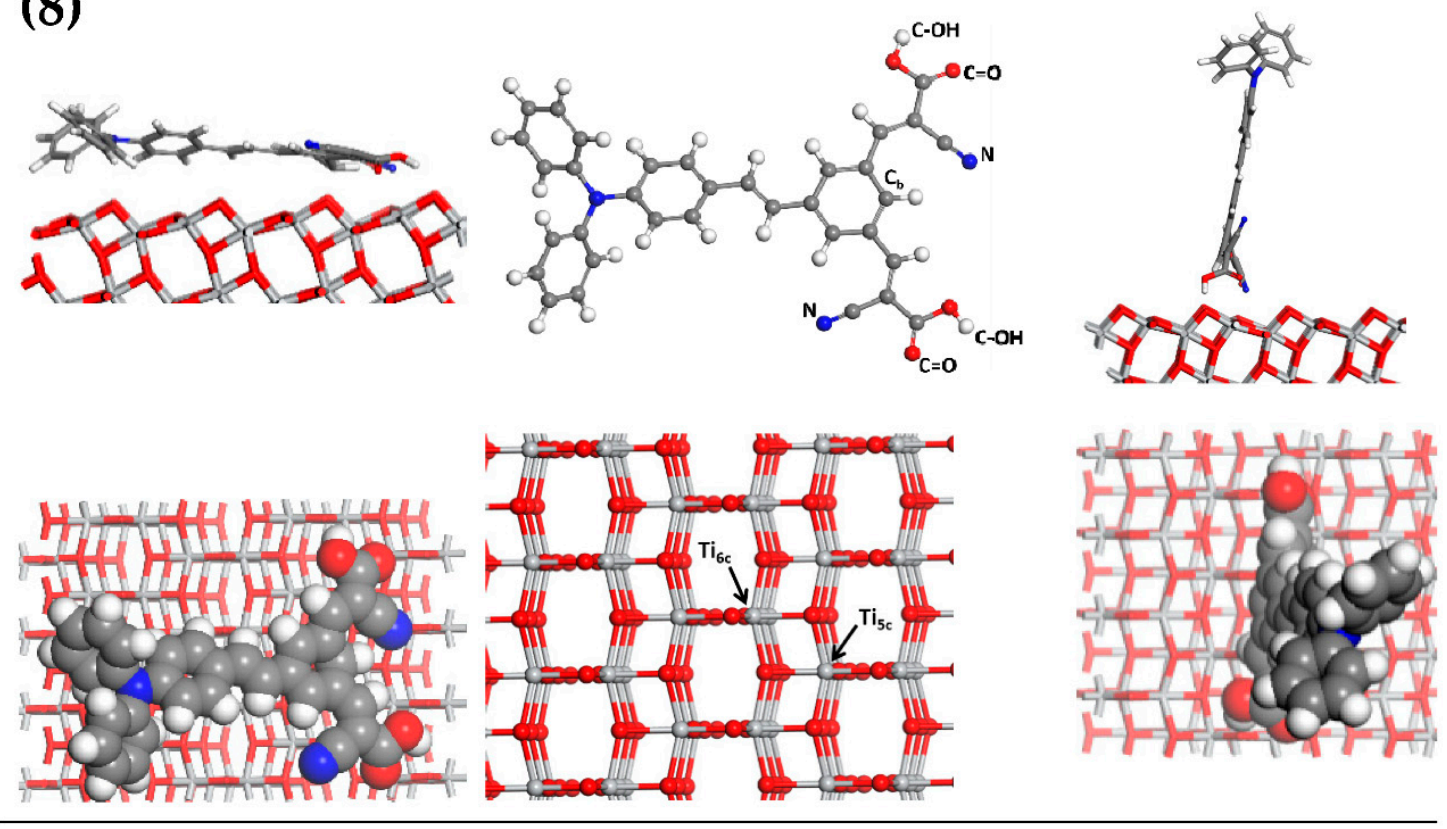

(10)
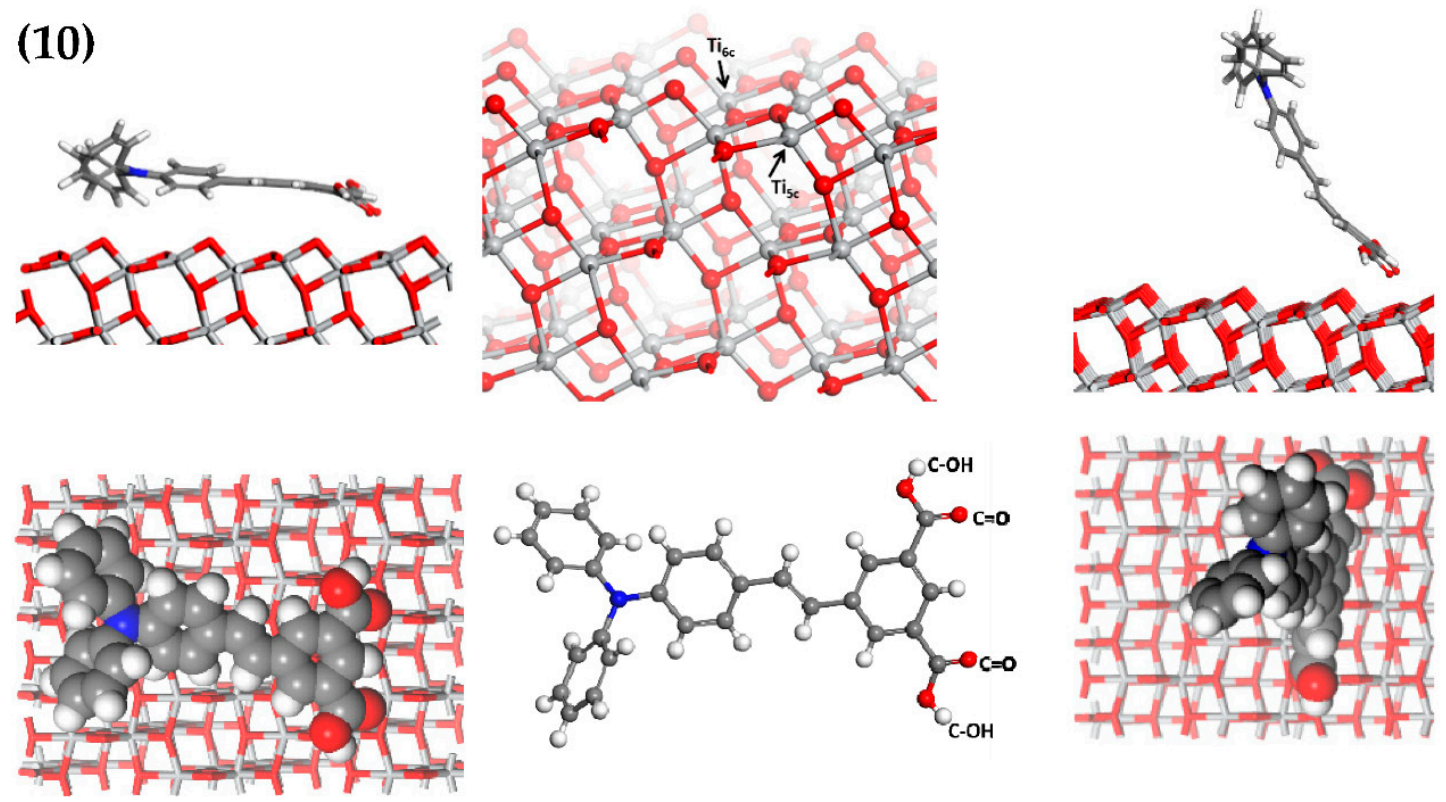

Figure 4. Atomistic modelling results of dyes (8) — top row and (10)—bottom row, oriented horizontally (left column) and vertically (right column) showing cross-sectional and plan views relative to the $\mathrm{TiO}_{2}$ surface. Central column shows dyes and the labels of specific atoms involved in dye/surface interactions, plus cross-sectional and plan views of $\mathrm{TiO}_{2}$. $\mathrm{Ti}_{5 \mathrm{c}}$ and $\mathrm{Ti}_{6 \mathrm{c}}$ refer to five- and six-coordinated $\mathrm{Ti}$, respectively. Color scheme: $\mathrm{O}-$ red; $\mathrm{Ti}$-light grey; $\mathrm{C}$-dark grey; $\mathrm{N}$-blue; $\mathrm{H}$-white. 
Dye (8) interacts with the $\mathrm{TiO}_{2}$ surface via its cyano nitrogen, carboxylic oxygen, and hydrogen, in both horizontal and vertical orientations (see Table 3). The horizontally oriented dye has an additional interaction between the benzene carbon (Figure 4) and surface oxygen, which, judging by its relatively short distance of $1.53 \AA$ suggests a covalent bond. The previously planar benzene ring distorts by approximately $40^{\circ}$ towards a surface apical oxygen, which results in the conversion of a double to single C-C bond.

Table 3. The dyes; dye moieties and their interaction distances with the surface; approximate range of the angle of inclination of the dyes' carbon backbone to the surface; the estimated projected surface area of the molecules on the surface based on their van der Waals outline.

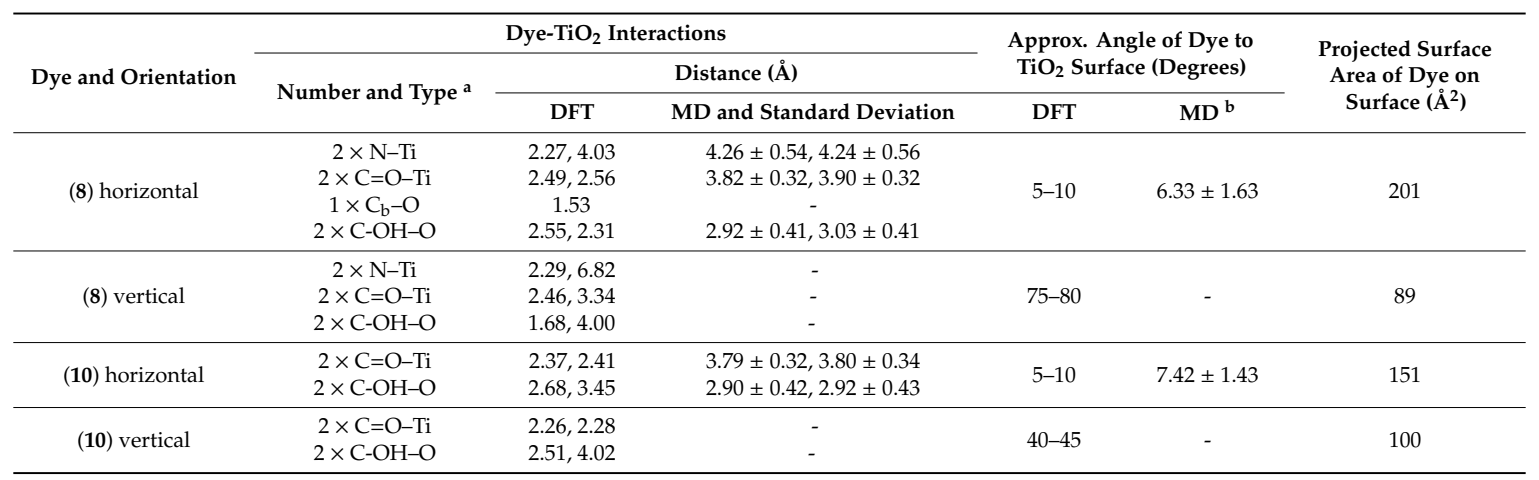

a $\mathrm{N}-\mathrm{Ti}$ : cyano-N to $\mathrm{Ti}_{5 c}$ (i.e., five-coordinated $\mathrm{Ti}$ ); $\mathrm{C}=\mathrm{O}-\mathrm{Ti}$ : carboxylic $\mathrm{O}$ to $\mathrm{Ti}_{5 c} ; \mathrm{C}_{\mathrm{b}-}-\mathrm{O}$ : Benzene $\mathrm{C}$ to surface $\mathrm{O}$;

$\mathrm{C}-\mathrm{OH}-\mathrm{O}$ : carboxylic $\mathrm{H}$ to surface $\mathrm{O}-$ see Figure 4 for dye and Ti labels. ${ }^{\mathrm{b}}$ Angle was measured using the two vectors:

1. triphenyl nitrogen and carbon on the benzene $\left(C_{b}\right)$ joining the two linkers; 2 . normal vector to the $\mathrm{TiO}_{2}$ surface.

Comparing the electron density of the horizontal and vertical orientations represented by Mulliken charges [64-67] reveals an increase in electron density around the distorted benzene ring, with an accompanying decrease in electron density dissipated across the closest surface titania. Dye (10) lacks cyano groups and interacts with the surface via its carboxylic oxygen and hydrogen, in both horizontal and vertical orientations (see Table 3), with the former exhibiting shorter interaction distances between the carboxylic oxygen and five-coordinated $\mathrm{Ti}$, than are seen in horizontally orientated dye (8). The $\mathrm{N}-\mathrm{Ti}$ and $\mathrm{C}=\mathrm{O}-\mathrm{Ti}$ distances exhibited by both dyes indicate covalent to ionic interactions, and the $\mathrm{C}-\mathrm{OH}-\mathrm{O}$ distances indicate hydrogen bonding and electrostatic interactions.

During the MD equilibration both molecules (8) and (10) became horizontal against the surface-indicating the influence of van der Waals and electrostatic interactions between the dye and surface-and remained so throughout the simulation of $40 \mathrm{~ns}$ (example snapshot in Supplementary Material Figure S1). As can be seen in Table 3, the MD interaction distances are generally longer than those measured from the DFT simulations, which is not surprising as MD simulations do not include electronic interactions. Such interactions are modeled via the force field parameters; hence the results of a molecular dynamics simulation depend on the suitability of the classical force field used. In this study, the $\mathrm{TiO}_{2}$ slab was kept rigid limiting closer interaction with the dye molecules. However, the reasonably short carboxylic hydrogen-to-surface distances and their nearly constant distributions (Figure 5) show that, at $298 \mathrm{~K}$, the molecules are stable in their horizontal configurations in close proximity to the surface. Moreover, for both dye molecules, the angles between the molecular plane and the slab surface agree very well with the DFT calculations (Table 3), and the dyes exhibit a number of dominant interactions with the $\mathrm{TiO}_{2}$ surface: covalent, hydrogen-bonds, van der Waals and electrostatic.

From our atomistic simulations we infer that in experimental devices, both dyes adsorb to the surface in horizontal orientations, which might change with an increase in dye concentration, i.e., if space becomes limited for horizontal, mono-layer dye packing, the molecules might be forced to pack closer together in more vertical than horizontal orientations. Multiple dye packing is the focus of our next study. 
The atomistic modelling work carried out using density functional theory, time dependent density functional theory, and molecular dynamics provides a deeper level of insight to the experimental work, with the proviso that the models are simplifications of the experimental systems and as such are subject to limitations, notwithstanding which the intention is to capture the essential interactions prevalent in a physical system.
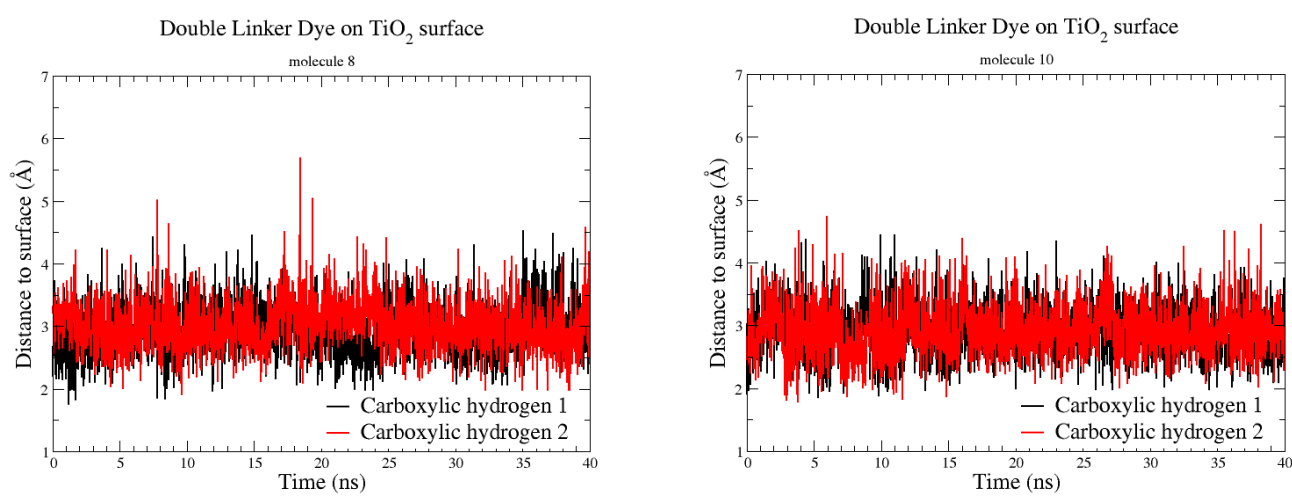

Figure 5. Distances between carboxylic hydrogens and $\mathrm{TiO}_{2}$ surface over the 40 ns molecular dynamics (MD) simulation.

\section{Conclusions}

Whilst organic DSC dyes are often designed using a donor-spacer-linker motif, this is usually hypothesized to be oriented vertically to the $\mathrm{TiO}_{2}$ surface. From our atomistic simulations we infer that in experimental devices, both dyes adsorb to the $\mathrm{TiO}_{2}$ surface in horizontal orientations. However, we modelled single dye molecules and so the orientation might change with increase in dye loading; i.e., if space becomes limited for horizontal, mono-layer dye packing, the molecules might be forced to pack closer together in more vertical than horizontal orientations. A similar effect has been reported previously for terephthalic acid on rutile [68]. Whilst this does not affect the donor-spacer-linker approach, it does affect the surface area that the dye molecules occupy, which dye moieties interact with the $\mathrm{TiO}_{2}$ surface, and how dyes should be designed moving forward. For example, for dye (8), the DFT unexpectedly shows dye: $\mathrm{TiO}_{2}$ distances short enough to suggest a bonding interaction between the benzene ring and the $\mathrm{TiO}_{2}$ surface which could influence where electron injection takes place from this dye into the $\mathrm{TiO}_{2}$. DSC device data do show better PCE for dye (8) which has a common triphenyl donor to (10) but two cyanoacrylate linker groups rather than two carboxylates. This is a similar trend to devices made from the structurally related single linker dyes [19]. However, we ascribe this mainly to broadened spectral response in line with the EQE data and the red-shifted light absorption observed both experimentally and by TDDFT. MD simulations emphasize that dye-surface interactions are not static which again agrees with experimental data for DSC devices which are known to improve with ageing in the first week after manufacture. Finally, photovoltaic device lifetime is an important parameter for technology commercialization. Whilst we have not reported this for these dyes in this paper, our previous work on related triphenylamine dyes [18] showed that they exhibited excellent stability for $1800 \mathrm{~h}$ of light soaking so we expect these dyes to also exhibit similar device stability.

Supplementary Materials: The following are available online at http://www.mdpi.com/1996-1073/13/18/4637/s1, Scheme S1 Synthetic pathway of diphenyl-(4-vinyl-phenyl)-amine (1); Scheme S2 Synthetic pathway of 5-bromo-1, 3-di-benzaldehyde (5); Scheme S3 Synthetic pathway of 1,3-dimethyl 5-bromoisophthalate (6); Scheme S4 Synthetic pathway of (E)-5-(4-(diphenylamino) styryl)isophthalaldehyde (7); Scheme S5 Synthetic pathway of 5-[(2-diphenylamino-phenyl)-vinyl]-isophthalic acid dimethyl ester (9); Figure S1 Snapshots from the 40 ns MD simulation of dyes; Figure S2 UV-visible spectra for (a) dyes dissolved in methanol and (b) dyes adsorbed onto a transparent, mesoporous $\mathrm{TiO}_{2}$ film; Figure S3 I-V curves for DSC devices prepared from (a) dye (8) and (b) dye (10).

Author Contributions: Individual contributions include conceptualization, P.J.H.; synthesis and device making, M.M.; synthesis, A.C.; synthesis and device data analysis; C.P.K., D.M.-R., E.W.J.; computational modelling, D.G., 
K.S., Y.-W.H.; supervision and funding acquisition, P.J.H., D.G. All authors have read and agreed to the published version of the manuscript.

Funding: We gratefully acknowledge funding from the EPSRC EP/P030068/1 (DMR, PJH), EP/P03165X/1 (D.G., K.S., Y.-W.H.), EP/M015254/2 (E.W.J., A.C.), the Iraqi Govt. for PhD funding (M.M.), EU SPARC-II (C.K.), and the UK National Mass Spectrometry Facility at Swansea University.

Computing Resources: We acknowledge use of Hartree Centre resources in this work. The Science and Technology Facilities Council (STFC) Hartree Centre is a research collaborator in association with IBM providing High Performance Computing platforms funded by the U.K.'s investment in e-Infrastructure. The Center aims to develop and demonstrate next generation software, optimized to take advantage of the move toward exa-scale computing.

Conflicts of Interest: The authors declare no conflict of interest.

\section{References}

1. O'Regan, B.; Grätzel, M. A low-cost, high-efficiency solar cell based on dye-sensitized colloidal TiO ${ }_{2}$ films. Nature 1991, 353, 737-740. [CrossRef]

2. Nazeeruddin, M.K.; De Angelis, F.; Fantacci, S.; Selloni, A.; Viscardi, G.; Liska, P.; Ito, S.; Takeru, B.; Grätzel, M. Combined Experimental and DFT-TDDFT Computational Study of Photoelectrochemical Cell Ruthenium Sensitizers. J. Am. Chem. Soc. 2005, 127, 16835-16847. [CrossRef] [PubMed]

3. Cao, Y.; Bai, Y.; Yu, Q.; Cheng, Y.; Liu, S.; Shi, D.; Gao, F.; Wang, P. Dye-Sensitized Solar Cells with a High Absorptivity Ruthenium Sensitizer Featuring a 2-(Hexylthio)thiophene Conjugated Bipyridine. J. Phys. Chem. C 2009, 113, 6290-6297. [CrossRef]

4. Nazeeruddin, M.K.; Péchy, P.; Grätzel, M. Efficient panchromatic sensitization of nanocrystalline $\mathrm{TiO}_{2}$ films by a black dye based on a trithiocyanato-ruthenium complex. Chem. Commun. 1997, 1, 1705-1706. [CrossRef]

5. Sun, Y.; Onicha, A.C.; Myahkostupov, M.; Castellano, F.N. Viable Alternative to N719 for Dye-Sensitized Solar Cells. ACS Appl. Mater. Interfaces 2010, 2, 2039-2045. [CrossRef]

6. Shiau, S.-Y.; Chang, C.-H.; Chen, W.-J.; Wang, H.-J.; Jeng, R.-J.; Lee, R.-H. Star-shaped organic semiconductors with planar triazine core and diketopyrrolopyrrole branches for solution-processed small-molecule organic solar cells. Dyes Pigments 2015, 115, 35-49. [CrossRef]

7. Yen, Y.-S.; Chou, H.-H.; Chen, Y.-C.; Hsu, C.-Y.; Lin, J.T. Recent developments in molecule-based organic materials for dye-sensitized solar cells. J. Mater. Chem. 2012, 22, 8734-8747. [CrossRef]

8. Chen, Y.-C.; Lin, J.T. Multi-anchored sensitizers for dye-sensitized solar cells. Sustain. Energy Fuels 2017, 1, 969-985. [CrossRef]

9. Abdalhadi, S.M.; Connell, A.; Zhang, X.; Wiles, A.A.; Davies, M.L.; Holliman, P.J.; Cooke, G. Convenient synthesis of EDOT-based dyes by $\mathrm{CH}$-activation and their application as dyes in dye-sensitized solar cells. J. Mater. Chem. A 2016, 4, 15655-15661. [CrossRef]

10. Connell, A.; Holliman, P.J.; Davies, M.L.; Gwenin, C.D.; Weiss, S.; Pitak, M.B.; Horton, P.N.; Coles, S.J.; Cooke, G. A Study of Dye Anchoring Points in Half-squarylium Dyes for Dye-Sensitized Solar Cells. J. Mater. Chem. A 2014, 2, 4055-4066. [CrossRef]

11. Connell, A.; Holliman, P.J.; Jones, E.W.; Furnell, L.; Kershaw, C.; Davies, M.L.; Gwenin, C.D.; Pitak, M.B.; Coles, S.J.; Cooke, G. Multiple linker Half-squarylium Dyes for Dye-Sensitized Solar Cells; Are Two Linkers Better than One? J. Mater. Chem. A 2015, 3, 2883-2894. [CrossRef]

12. Holliman, P.J.; Kershaw, C.P.; Jones, E.W.; McGettrick, J.; Geatches, D.; Metz, S.; Sen, K.; Tizzard, G.J.; Coles, S.J. Novel Benzothiazole Half-Squaraines: Model Chromophores to Study Dye-TiO 2 Interactions in Dye-Sensitized Solar Cells. J. Mater. Chem. A. 2020. paper under review.

13. Yao, Z.; Zhang, M.; Li, R.; Yang, L.; Qiao, Y.; Wang, P. A Metal-Free N-Annulated Thienocyclopentaperylene Dye: Power Conversion Efficiency of $12 \%$ for Dye-Sensitized Solar Cells. Angew. Chem. Int. Ed. 2015, 54, 5994-5998. [CrossRef]

14. Yao, Z.; Zhang, M.; Wu, H.; Yang, L.; Li, R.; Wang, P. Donor/Acceptor Indenoperylene Dye for Highly Efficient Organic Dye-Sensitized Solar Cells. J. Am. Chem. Soc. 2015, 137, 3799-3802. [CrossRef]

15. Yella, A.; Mai, C.-L.; Zakeeruddin, S.M.; Chang, S.-N.; Hsieh, C.-H.; Yeh, C.-Y.; Grätzel, M. Molecular engineering of push-pull porphyrin dyes for highly efficient dye-sensitized solar cells: The role of benzene spacers. Angew. Chem. Int. Ed. 2014, 53, 2973-2977. [CrossRef] [PubMed] 
16. Kakiage, K.; Aoyama, Y.; Yano, T.; Oya, K.; Kyomen, T.; Hanaya, M. Fabrication of a high-performance dye-sensitized solar cell with $12.8 \%$ conversion efficiency using organic silyl-anchor dyes. Chem. Commun. 2015, 51, 6315-6317. [CrossRef]

17. Kakiage, K.; Aoyama, Y.; Yano, T.; Oya, K.; Fujisawa, J.; Hanaya, M. Highly-efficient dye-sensitized solar cells with collaborative sensitization by silyl-anchor and carboxy-anchor dyes. Chem. Commun. 2015, 51, 15894-15897. [CrossRef]

18. Zhang, F.; Luo, Y.-H.; Song, J.-S.; Guo, X.-Z.; Liu, W.-L.; Maa, C.-P.; Huang, Y.; Ge, M.-F.; Bo, Z.; Meng, Q.-B. Triphenylamine-based dyes for dye-sensitized solar cells. Dyes Pigments 2009, 81, 224-230. [CrossRef]

19. Holliman, P.J.; Mohsen, M.; Connell, A.; Davies, M.L.; Al-Salihi, K.; Pitak, M.B.; Tizzard, G.J.; Coles, S.J.; Harrington, R.W.; Clegg, W.; et al. Ultra-fast Co-Sensitization and Tri-Sensitization of Dye-Sensitized Solar Cells with N719, SQ1 and Triarylamine Dyes. J. Mater. Chem. 2012, 22, 13318-13327. [CrossRef]

20. Hao, Y.; Tian, H.; Cong, J.; Yang, W.; Bora, I.; Sun, L.; Boschloo, G.; Hagfeldt, A. Triphenylamine Groups Improve Blocking Behaviour of Phenoxazine Dyes in Cobalt-Electrolyte-Based Dye-Sensitized Solar Cells. ChemPhysChem 2014, 15, 3476-3483. [CrossRef]

21. Wan, Z.; Jia, C.; Wang, Y.; Yao, X. Dithiafulvenyl-triphenylamine organic dyes with alkyl chains for efficient coadsorbent-free dye sensitized solar cells. RSC Adv. 2015, 5, 50813-50820. [CrossRef]

22. Chen, S.; Pei, J.; Pang, Z.; Wu, W.; Yu, X.; Zhang, C. Axial-symmetric conjugated group promoting intramolecular charge transfer performances of triphenylamine sensitizers for dye-sensitized solar cells. Dyes Pigments 2020, 174, 108029-108038. [CrossRef]

23. Ferdowsi, P.; Saygili, Y.; Jazaeri, F.; Edvinsson, T.; Mokhtari, J.; Zakeeruddin, S.M.; Liu, Y.; Grätzel, M.; Hagfeldt, A. Molecular Engineering of Simple Metal-Free Organic Dyes Derived from Triphenylamine for Dye-Sensitized Solar Cell Applications. ChemPhysChem 2020, 13, 212-220. [CrossRef] [PubMed]

24. Wu, Z.-S.; Song, X.-C.; Liu, Y.-D.; Zhang, J.; Wang, H.-S.; Chen, Z.-J.; Liu, S.; Weng, Q.; An, Z.-W.; Guo, W.-J. New organic dyes with varied arylamine donors as effective co-sensitizers for ruthenium complex N719 in dye sensitized solar cells. J. Power Sources 2020, 451, 227776-227785. [CrossRef]

25. Clifford, J.N.; Palomares, E.; Nazeeruddin, M.K.; Thampi, R.; Grätzel, M.; Durrant, J.R. Multistep Electron Transfer Processes on Dye Co-sensitized Nanocrystalline $\mathrm{TiO}_{2}$ Films. J. Am. Chem. Soc. 2004, 126, 5670-5761. [CrossRef]

26. Choi, H.; Kim, S.; Kang, S.O.; Ko, J.; Kang, M.-S.; Clifford, J.N.; Forneli, A.; Palomares, E.; Nazeeruddin, M.K.; Grätzel, M. Stepwise Cosensitization of Nanocrystalline $\mathrm{TiO}_{2}$ Films Utilizing $\mathrm{Al}_{2} \mathrm{O}_{3}$ Layers in Dye-Sensitized Solar Cells. Angew. Chem. Int. Ed. 2008, 47, 8259-8263. [CrossRef]

27. Clifford, J.N.; Forneli, A.; Chen, H.; Torres, T.; Tan, S.; Palomares, E. Co-sensitized DSCs: Dye selection criteria for optimized device $V_{\mathrm{oc}}$ and efficiency. J. Mater. Chem. 2011, 21, 1693-1696. [CrossRef]

28. Lan, C.-M.; Wu, H.-P.; Pan, T.-Y.; Chang, C.-W.; Chao, W.-S.; Chen, C.-T.; Wang, C.-L.; Lin, C.-Y.; Diau, E.W.-G. Enhanced photovoltaic performance with co-sensitization of porphyrin and an organic dye in dye-sensitized solar cells. Energy Environ. Sci. 2012, 5, 6460-6464. [CrossRef]

29. Yella, A.; Lee, H.-W.; Tsao, H.N.; Yi, C.; Chandiran, A.K.; Nazeeruddin, M.K.; Diau, E.W.-G.; Yeh, C.-Y.; Zakeeruddin, S.M.; Grätzel, M. Porphyrin-Sensitized Solar Cells with Cobalt (II/III)-Based Redox Electrolyte Exceed 12 Percent Efficiency. Science 2011, 334, 629-634. [CrossRef]

30. Holliman, P.J.; Davies, M.L.; Connell, A.; Vaca Velasco, B.; Watson, T.M. Ultra-fast dye sensitisation and co-sensitisation for dye sensitized solar cells. Chem. Commun. 2010, 46, 7256-7258. [CrossRef]

31. Davies, M.L.; Watson, T.; Holliman, P.J.; Connell, A.; Worsley, D. In situ monitoring of room temperature ultra-fast sensitization for dye sensitized solar cells. Chem. Commun. 2014, 50, 12512-12514. [CrossRef] [PubMed]

32. Holliman, P.J.; Al-Salihi, K.J.; Connell, A.; Davies, M.L.; Jones, E.W.; Worsley, D.A. Development of Selective, Ultra-fast Multiple Co-sensitization to Control Dye Loading in Dye-Sensitized Solar Cells. RSC Adv. 2014, 4, 2515-2522. [CrossRef]

33. Wu, G.; Kong, F.; Zhang, Y.; Zhang, X.; Li, J.; Chen, W.; Zhang, C.; Dai, S. Effect of different acceptors in di-anchoring triphenylamine dyes on the performance of dye-sensitized solar cells. Dyes Pigments 2014, 105, 1-6. [CrossRef]

34. Sen, A.; Gro $\beta$, A. Does Involving Additional Linker Always Increase the Efficiency of an Organic Dye for p-Type Dye-Sensitized Solar Cells? ACS Appl. Energy Mater. 2019, 2, 6341-6347. [CrossRef] 
35. Wang, Q.; Moser, J.-E.; Grätzel, M. Electrochemical Impedance Spectroscopic Analysis of Dye-Sensitized Solar Cells. J. Phys. Chem. B 2005, 109, 14945-14953. [CrossRef] [PubMed]

36. Han, J.; Fan, F.; Xu, C.; Lin, S.; Wei, M.; Duan, X.; Wang, Z.L. ZnO nanotube-based dye-sensitized solar cell and its application in self-powered Devices. Nanotechnology 2010, 21, 405203. [CrossRef]

37. Vaghasiya, J.V.; Sonigara, K.K.; Soni, S.S.; Tan, S.C. Dual Functional Hetero-anthracene Based Single Component Organic Ionic Conductors as Redox Mediator cum Light Harvester for Solid State Photoelectrochemical Cells. J. Mater. Chem. A 2018, 6, 4868-4877. [CrossRef]

38. Chal, P.; Shit, A.; Nandi, A.K. Dye-Sensitized Solar Cell from a New Organic n-Type Semiconductor/Polyaniline Composite: Insight from Impedance Spectroscopy. J. Mater. Chem. C 2016, 4, 272-285. [CrossRef]

39. Li, J.-Y.; Chen, C.-Y.; Lee, C.-P.; Chen, S.-C.; Lin, T.-H.; Tsai, H.-H.; Ho, K.-C.; Wu, C.-G. Unsymmetrical Squaraines Incorporating the Thiophene Unit for Panchromatic Dye-Sensitized. Sol. Cells Org. Lett. 2010, 12, 5454-5457. [CrossRef]

40. Hagberg, D.P.; Marinado, T.; Karlsson, K.M.; Nonomura, K.; Qin, P.; Boschloo, G.; Brinck, T.; Hagfeldt, A.; Sun, L. Tuning the HOMO and LUMO Energy Levels of Organic Chromophores for Dye Sensitized Solar Cells. J. Org. Chem. 2007, 72, 9550-9556. [CrossRef]

41. Yum, J.-H.; Walter, P.; Huber, S.; Rentsch, D.; Geiger, T.; Nüesch, F.; De Angelis, F.; Grätzel, M.; Nazeeruddin, M.K. Efficient Far Red Sensitization of Nanocrystalline $\mathrm{TiO}_{2}$ Films by an Unsymmetrical Squaraine Dye. J. Am. Chem. Soc. 2007, 129, 10320-10321. [CrossRef] [PubMed]

42. Peng, B.; Yang, S.; Li, L.; Cheng, F.; Chen, J. A density functional theory and time-dependent density functional theory investigation on the anchor comparison of triarylamine-based dyes. J. Chem. Phys. 2010, 132, 034305. [CrossRef]

43. De Angelis, F.; Fantacci, S.; Selloni, A.; Nazeeruddin, M.K.; Grätzel, M. First-Principles Modeling of the Adsorption Geometry and Electronic Structure of $\mathrm{Ru}(\mathrm{II})$ Dyes on Extended $\mathrm{TiO}_{2}$ Substrates for Dye-Sensitized Solar Cell Applications. J. Phys. Chem. C 2010, 114, 6054-6061. [CrossRef]

44. Oprea, C.I.; Gîrţu, M.A. Structure and Electronic Properties of $\mathrm{TiO}_{2}$ Nanoclusters and Dye-Nanocluster Systems Appropriate to Model Hybrid Photovoltaic or Photocatalytic Applications. Nanomaterials 2019, 9, 357. [CrossRef] [PubMed]

45. Pastore, M.; De Angelis, F. Intermolecular Interactions in Dye-Sensitized Solar Cells: A Computational Modeling Perspective. J. Phys. Chem. Lett. 2013, 4, 956-974. [CrossRef]

46. Anselmi, C.; Mosconi, E.; Pastore, M.; Ronca, E.; De Angelis, F. Adsorption of organic dyes on $\mathrm{TiO}_{2}$ surfaces in dye-sensitized solar cells: Interplay of theory and experiment. Phys. Chem. Chem. Phys. 2012, 14, 15963-15974. [CrossRef]

47. De Angelis, F.; Fantacci, S.; Selloni, A.; Nazeeruddin, M.K.; Grätzel, M. Time-Dependent Density Functional Theory Investigations on the Excited States of $\mathrm{Ru}(\mathrm{II})$-Dye-Sensitized $\mathrm{TiO}_{2}$ Nanoparticles: The Role of Sensitizer Protonation. J. Am. Chem. Soc. 2007, 129, 14156-14157. [CrossRef]

48. Persson, P.; Lundqvist, M.J. Calculated Structural and Electronic Interactions of the Ruthenium Dye N3 with a Titanium Dioxide Nanocrystal. J. Phys. Chem. B 2005, 109, 11918-11924. [CrossRef]

49. De Angelis, F.; Fantacci, S.; Mosconi, E.; Nazeeruddin, M.K.; Grätzel, M. Absorption Spectra and Excited State Energy Levels of the N719 Dye on $\mathrm{TiO}_{2}$ in Dye-Sensitized Solar Cell Models. J. Phys. Chem. C 2011, 115, 8825-8831. [CrossRef]

50. Karami, M.; Beni, A.R.S.; Hosseinzadeh, B. A periodic density functional theory investigation of tetrazole derivatives adsorbed on anatase $\mathrm{TiO}_{2}$ surface applied in dye-sensitized solar cell. Surf. Sci. 2017, 664, 110-119. [CrossRef]

51. Clark, S.J.; Segall, M.D.; Pickard, C.J.; Hasnip, P.J.; Probert, M.I.J.; Refson, K.; Payne, M.C. First principles methods using CASTEP. Z. Kristallogr. 2005, 220, 567-570. [CrossRef]

52. Kohn, W.; Sham, L.J. Self-Consistent Equations Including Exchange and Correlation Effects. Phys. Rev. 1965, 140, A1133. [CrossRef]

53. Hohenberg, P.; Kohn, W. Inhomogeneous Electron Gas. Phys. Rev. 1964, 136, 864. [CrossRef]

54. Payne, M.C.; Teter, M.P.; Allan, D.C.; Arias, T.A.; Joannopoulous, J.D. Iterative minimization techniques for ab initio total-energy calculations: Molecular dynamics and conjugate gradients. Rev. Mod. Phys. 1992, 64, 1045. [CrossRef] 
55. Dassault Systèmes. Dassault Systèmes BIOVIA, Materials Studio v2016; Dassault Systèmes: San Diego, CA, USA, 2016.

56. Phillips, J.C.; Braun, R.; Wang, W.; Gumbart, J.; Tajkhorshid, E.; Villa, E.; Chipot, C.; Skeel, R.D.; Kale, L.; Schulten, K. Scalable Molecular Dynamics with NAMD. J. Comput. Chem. 2005, 26, 1781-1802. [CrossRef] [PubMed]

57. Humphrey, W.; Dalke, A.; Schulten, K. VMD-Visual Molecular Dynamics. J. Mol. Graph. 1996, 14, $33-38$. [CrossRef]

58. Runge, E.; Gross, E.K.U. Density-Functional Theory for Time-Dependent Systems. Phys. Rev. Lett. 1984, 52, 997-1000. [CrossRef]

59. Petersilka, M.; Gossmann, U.J.; Gross, E.K.U. Excitation Energies from Time-Dependent Density-Functional Theory. Phys. Rev. Lett. 1996, 76, 1212-1215. [CrossRef]

60. Casida, M. Time-dependent density functional response theory for molecules. In Recent Advances in Density Functional Methods, Part I; Chong, D., Ed.; World Scientific: Singapore, 1995; p. 155.

61. Carsten, U. Time-Dependent Density-Functional Theory: Concepts and Applications (Oxford Graduate Texts); Oxford University Press: New York, NY, USA, 2012.

62. Neese, F. The ORCA Program System. WIREs Comput. Mol. Sci. 2012, 2, 73-78. [CrossRef]

63. Zakeeruddin, S.M.; Humphry-Baker, R.; Liska, P.; Charvet, R.; Comte, P.; Nazeeruddin, M.K.; Péchy, P.; Takata, M.; Miura, H.; Uchida, S.; et al. High-Efficiency Organic-Dye-Sensitized Solar Cells Controlled by Nanocrystalline- $\mathrm{TiO}_{2}$ Electrode Thickness. Adv. Mater. 2006, 18, 1202-1205.

64. Mulliken, R.S. Electronic population analysis on LCAO-MO molecular wavefunctions. J. Chem. Phys. 1955, 23, 1833-1840. [CrossRef]

65. Mulliken, R.S. Electronic population analysis on LCAO-MO molecular wave functions. II. overlap populations, bond orders, and covalent bond energies. J. Chem. Phys. 1955, 23, 1841-1846. [CrossRef]

66. Mulliken, R.S. Electronic population analysis on LCAO-MO molecular wave functions. III. effects of hybridization on overlap and gross AO populations. J. Chem. Phys. 1955, 23, 2338-2342. [CrossRef]

67. Mulliken, R.S. Electronic population analysis on LCAO-MO molecular wave functions. IV. bonding and antibonding in LCAO and valence-bond theories. J. Chem. Phys. 1955, 23, 2343-2346. [CrossRef]

68. Rahe, P.; Nimmrich, M.; Nefedov, A.; Naboka, M.; Wöll, C.; Kühnle, A. Transition of Molecule Orientation during Adsorption of Terephthalic Acid on Rutile $\mathrm{TiO}_{2}(110)$. J. Phys. Chem. C 2009, 113, 17471-17478. [CrossRef] 